\title{
THE RISK FACTOR OF HYPERTENSION AND SEX TO CORONARY ARTERY DISEASE AT JEMURSARI ISLAMIC HOSPITAL SURABAYA
}

\author{
Hanin Dhany Robby \\ Department of Biostatistics and Population \\ Faculty of Public Health, Universitas Airlangga \\ Corespondence Address: Hanin Dhany Robby \\ Email: hanin.dhany-13@fkm.unair.ac.id
}

\begin{abstract}
Coronary Artery Disease (CAD) is one of the non-communicable diseases which need concern nowadays because it leads cause of the death worldwide and estimates attacking more people in year by year. The risk factors of CAD divided into two categories such as modifiable risk and non-modifiable risk presented in this study including hypertension and sex. The study aimed to analyze the risk factor of hypertension and sex to CAD in patients who visited Cardiovascular Polyclinic of Jemursari Islamic Hospital in April 2017. The research was non-reactive study with analytical research design involved 850 respondents as the sample which chosen by systematic random sampling from 2474 people as the population. The data were analyzed with $\mathrm{R}$ using test of chi square and test of binary logistic regression. The result showed in chi square test that there was a relationship between hypertension and sex with CAD. In addition, factors of hypertension and sex were significantly related to CAD with the test of binary logistic regression. In conclusion, hypertension and sex were the risk factors of CAD and hypertension and sex were associated with CAD. The study suggested taking antihypertensive drugs for the treatment of hypertension in order to reduce the CAD risk, to reduce the consumption of salt and categorized the modifiable risk for men and women as the prevention from sudden coronary death.
\end{abstract}

Keywords: coronary artery disease, hypertension, risk factor, sex

\section{INTRODUCTION}

Coronary Artery Disease (CAD) still becomes the leading cause of death worldwide in non-communicable disease (Hanson et al., 2013). CAD refers to the pathologic process of atherosclerosis affecting the coronary arteries (Hanson et al., 2013). CAD is one of cardiovascular disease which predicted to be the main cause of death globally within the next 15 years particularly in developing countries (Hansson, 2005). Indonesia as one of developing countries had a high prevalence of CAD. According to 2013 Basic Health Research (Riskesdas), conducted by Health Ministry of Republic of Indonesia, the prevalence of CAD estimated $1.5 \%$ of the Indonesia population (Kementerian Kesehatan RI, 2013). Moreover, the health survey estimated 375,127 individuals with CAD in East Java Province by 2013 (Pusat
Data dan Informasi Kesehatan RI, 2014). The province's ranking was $2^{\text {nd }}$ highest of CAD among other provinces in Indonesia, Surabaya, one of the cities in East Java Province, also indicated a high prevalence of CAD based on the data from Jemursari Islamic Hospital which located at the downtown of Surabaya. The medical record of Jemursari Islamic Hospital noted 5,649 outpatients have CAD between January-July 2017 (Medical Record of RSI Jemursari, 2017).

CAD factors divide into two types, non-modifiable risk and modifiable risk. The non-modifiable risks for CAD are age, race, sex, and heredity of CAD (Rosendoff et al., 2015). Several studies found the majority sex who had CAD were male (Hansson, 2005; Yulsam et al., 2015). The modifiable risks are several risks that can be managed through lifestyle and treatment 
(Hanson et al., 2013) including hypertension.

Hypertension is an independent risk factor for CAD for all age or race or sex based on epidemiological studies (Rosendoff et al., 2015). The $7^{\text {th }}$ Report of the Joint National Committee used the definition of hypertension as systolic blood pressure (SBP) of $\geq 140 \mathrm{mmHg}$ or diastolic blood pressure (DBP) of $\geq 90 \mathrm{mmHg}$ and/or the current treatment of antihypertensive drugs (Joint National Committee VII, 2004). According to the result of 2013 Basic Health Research, the prevalence of hypertension in age $\geq 18$ years old estimated $25.8 \%$ of the Indonesia population (Kementerian Kesehatan RI, 2013).

Sex is an important variable for understanding the risk factor of CAD nowadays. By identifying sex into research can lead better science and improve the prevention, diagnosis, and treatment both males and females in CAD (Humphries et al., 2017). The risk factor of CAD in both men and women could be difference because their biological mechanism is also different. Some studies seemed to believe that risk factor of CAD in women is a unique case due to hormone and reproduction (Mackay \& Mensah, 2004). Referring to those facts force us to do the most recent research of CAD risk factor in order to consider the prediction, prevention, and treatment. Besides, risk factor analysis can help the primary health care provider to identify patients who need more intensive diagnosis and treatment. Therefore, we need to analyze the risk factors of CAD particularly sex.

As mentioned by Dinas Kesehatan of East Java Province at Health Report 2015, Surabaya city had 137,337 patients with hypertension as the highest prevalence of hypertension among other cities and regions in East Java Province (Dinas Kesehatan Jawa Timur, 2016). Another fact, as stated by Dinas Kesehatan of Surabaya, hypertension was ranked in 7 among top ten the most diseases in
Surabaya during January - December 2016 (Dinas Kesehatan Kota Surabaya, 2017). Therefore, discovering those data assured this study to investigate the risk factor of CAD from hypertension variable. Jemursari Islamic Hospital located in Surabaya has the cardiovascular polyclinic and received 8520 patients in 2016. Its medical record revealed that the cardiovascular polyclinic diagnosed 4371 patients with CAD and 992 patients with hypertension during September 1, 2016 February 28, 2017. The study chose this hospital for its huge record of CAD patients and hypertension patients to research the risk factor of CAD.

This study sought to analyze the risk factors of hypertension and sex to CAD at Jemursari Islamic Hospital Surabaya as 18,345 outpatients visited its Cardiovascular Polyclinic between January-July 2017. This study also could provide the data for the recent situation of CAD in Indonesia especially in Surabaya due to a large population for this research.

\section{METHODS}

The research was a non-reactive for using the medical record from Jemursari Islamic Hospital Surabaya because the respondents or the subjects of this study were not aware as part of the research project (Lee, 2000). The study conducted analytical research design with crosssectional approach to identify the risk factor of Hypertension and sex to CAD. It took the secondary data of outpatients attended Cardiovascular Polyclinic of Jemursari Islamic Hospital Surabaya in April 2017. The population was 2,474 patients and the sample involved 850 patients using systematic random sampling.

The research variables were CAD status (yes and no), Hypertension status (yes and no) and sex (female and male) from the medical record of outpatients of Cardiovascular Polyclinic. Data collecting took directly from the medical record as 
the secondary data from the hospital information system especially the unit of medical record of Jemursari Islamic Hospital. All of disease code categorized as stated by ICD-10 (International Statistical Classification of Diseases and Related Health Problems 10) which defines the universe of diseases, disorders, injuries and other related health conditions for all clinical and research purposes (WHO, 2016). The code disease for CAD was I25.4 or Coronary Artery Aneurysm and hypertension with the code of I11.9 and I10. The study was approved by the local ethics committee and the hospital itself. Statistical analysis used R Program version 3.3.2 with regression of binary logistic test for analyzing the multivariable with nominal variable and with chi square test for analyzing the relationship between the independent and the dependents. Statistical significance was assumed when P was $<0.05$ (two-tailed).

\section{RESULTS}

The distribution of characteristic respondents divided into three variables which were $\mathrm{CAD}$, hypertension and sex. All of variables categorized into two groups describing the frequency and its percentage. Among those variables, hypertension and sex were treated as independent variables.

Table 1. Frequency Distribution of CAD

\begin{tabular}{lcc}
\hline CAD & Frequency & $\begin{array}{c}\text { Percentage } \\
(\boldsymbol{\%})\end{array}$ \\
\hline Yes & 366 & 43.1 \\
\hline No & 484 & 56.9 \\
\hline Total & 850 & 100 \\
\hline $\begin{array}{c}\text { Source:Medical } \\
\text { Hospital, 2017 }\end{array}$ & & \\
\hline
\end{tabular}

Table 1 described the result that the number of respondents with no CAD was more than those people with CAD.

Table 2. Frequency Distribution of Hypertension

\begin{tabular}{|c|c|c|}
\hline Hypertension & Frequency & $\begin{array}{c}\text { Percentage } \\
(\%)\end{array}$ \\
\hline Yes & 597 & 70.2 \\
\hline No & 253 & 29.8 \\
\hline Total & 850 & 100 \\
\hline
\end{tabular}

The result of table 2 described that the frequency of respondents with Hypertension was more than those patients with no Hypertension. The most hypertension was essential hypertension and hypertensive heart disease with or without congestive heart failure.

Table 3. Frequency Distribution of Sex

\begin{tabular}{lcc}
\hline Sex & Frequency & $\begin{array}{c}\text { Percentage } \\
(\mathbf{\%})\end{array}$ \\
\hline Male & 413 & 48.6 \\
\hline Female & 437 & 51.4 \\
\hline Total & 850 & 100 \\
\hline $\begin{array}{c}\text { Source:Medical } \\
\text { Hospital, 2017 }\end{array}$ & Record & of \\
\hline
\end{tabular}

Table 3 summarized the entire of sex characteristic from the respondents that the female patients were more than the male patients. The difference between male group and female group was not too far, only $2.8 \%$.

Table 4 showed the relationship between independent variables and CAD using Chi Square test. The relationship of hypertension with $\mathrm{CAD}$ was statistically significant where $\mathrm{p}$ value $<0.05$. It also same for the interaction between sex and CAD showed a significant relationship where $p$ value $<0.05$. 
Table 4. The Chi Square Test of the Independents Variables with CAD

\begin{tabular}{|c|c|c|c|c|c|c|}
\hline \multirow{2}{*}{ Variable } & \multirow{2}{*}{ Category } & \multicolumn{4}{|c|}{ CAD } & \multirow[b]{2}{*}{ p Value } \\
\hline & & Yes & $\%$ & No & $\%$ & \\
\hline \multirow[t]{2}{*}{ Hypertension } & Yes & 234 & 39.2 & 363 & 60.8 & \multirow[t]{2}{*}{0.0001258} \\
\hline & No & 132 & 52.2 & 121 & 47.8 & \\
\hline \multirow[t]{2}{*}{ Sex } & Male & 206 & 49.9 & 207 & 50.1 & \multirow[t]{2}{*}{0.0006307} \\
\hline & Female & 160 & 36.6 & 277 & 63.4 & \\
\hline
\end{tabular}

Table 5. The Binary Logistic Regression Test of the Risk of CAD

\begin{tabular}{lccc}
\hline Variable & B & $\begin{array}{c}\text { Std. } \\
\text { Error }\end{array}$ & p \\
\hline Intercept & -0.193 & 0.148 & 0.193 \\
\hline $\begin{array}{l}\text { Hypertension } \\
\text { (Yes) }\end{array}$ & -0.491 & 0.153 & 0.001 \\
\hline Sex(Male) & 0.515 & 0.141 & 0.000 \\
\hline
\end{tabular}

The binary logistic regression was used to calculate a function model for evaluation whether the risk factors influenced CAD event. Table 5 showed that hypertension and sex were included as the risk factor of $\mathrm{CAD}$ because each variable has $p$ value $<0.05$. It also enabled the public health stakeholder to determine which characteristics were independently associated with the CAD event.

$B$ was the value for the model to predict the probability from independent variables determined the dependent variable. The estimated model of binary regression logistic for the risk factor of hypertension and sex to $\mathrm{CAD}$ was written below,

$$
\mathrm{f}(\mathrm{z})=\frac{1}{1+e^{0.193+0.491(\text { Yes })-0.515(\text { Male })}}
$$

Interpreting the estimate from binary logistic regression test was also important in order to know the probability from each risk factor. The probability to occur CAD for a male patient who had hypertension was 0.49. In other risk factors, the probability from a female patient who had hypertension to occur CAD was 0.335 . For the men who had not a history of hypertension, the probability was 0.58 to present CAD. As the women, they who had not hypertension, the probability to get CAD event was 0.45 .

\section{DISCUSSION}

Hypertension is not only the strongest risk in CAD but also for all almost cardiovascular diseases such as left ventricular hypertrophy, valvular heart diseases, and cardiac arrhythmias (Kjeldsen, 2017). It has become one of the major cardiovascular disease risk factors and the second major of risk factors after alcohol in low mortality developing countries including Indonesia by 5\% (Mackay \& Mensah, 2004). The significant relationship between hypertension and CAD occurred because the high blood pressure increases the blood flow faster so result the damage in the blood vessel (Naga, 2012).

The result from the study that hypertension was a significant as the CAD risk factors compared to the study conducted by Xu et al. (2017) which also showed same result for a significant determinant between hypertension and CAD. Moreover, their study supported the result of hypertension was higher in women than in men $(\mathrm{Xu}$ et al., 2017).However, the result was contrary to a study from the University of Ottawa Heart Institute which aimed to identify the interaction between hypertension and highrisk CAD (Yang et al., 2015).

Patients with hypertension have a $\mathrm{J}$ shaped relationship between blood pressure and morbidity or mortality particularly to those patients with CAD 
(Jennings, 2015). The J shaped relationship was a curve that explained the lower blood pressure may be related to increased mortality in various cardiovascular diseases (Lee et al., 2017).Although many research has been questioning this theoretical reason but this curve was strong theory particularly to those with CAD (Jennings, 2015). Blood flow to the myocardium occurs during diastole so perfusion pressure may be impaired when there is a combination of obstructive coronary artery disease and low diastolic pressure. Furthermore, many people with hypertension develop left ventricular hypertrophy. The combined effects of low perfusion pressure and obstructive coronary disease are likely to be enhanced when there is a thicker myocardium as the sub-endocardial layer is particularly vulnerable to ischemia (Jennings, 2015).

The risk of cardiovascular disease doubles for every ten point increase in diastolic blood pressure or every 20 point increase in systolic blood pressure (Mackay \& Mensah, 2004). This fact has been shown for all ages (Kjeldsen, 2017). The relationship with blood pressure extends from high blood pressure levels to relatively low values of $110-115 \mathrm{mmHg}$ for systolic blood pressure and 70-75 $\mathrm{mmHg}$ for diastolic blood pressure. Systolic blood pressure is a more potent predictor of occasions than diastolic blood pressure after the age of fifty years (Vishram et al., 2012). Systolic blood pressure and isolated systolic hypertension were major CAD risk factors in both sexes at all ages (James et al., 2014). In patients at the age of $<50$, diastolic blood pressure was the strongest predictor of CAD risk but contrary to the patients at the age of 60 and older, it was negatively related to CAD risk so that pulse pressure became remarkable to systolic blood pressure (Franklin et al., 2001). In addition, diastolic blood pressure $<60 \mathrm{mmHg}$ also associated with increased risk of CAD only for patients with atherosclerosis (McEvoy et al., 2017).
It still believed that major risk factors from hypertension can be changed (Kotseva et al., 2012). Information such as hypertension is always available including sex, age and diabetes history ( $\mathrm{Xu}$ et al., 2017). The early diagnosis of CAD can help in determining life style changes in high risk patients and reduce their complications. The high risk patients need to be considered by health services as the candidates for more aggressive management that may include cardiac cauterization (Xu et al., 2017).

There was uncommon finding about our study. Unlike the study from Zahrawardani (2013), this research revealed that the patients with hypertension and no CAD were higher than those with hypertension and CAD (see table 4). We assumed the patients with hypertension used to see the doctor every month to be checked and have medications refilled or adjusted. They frequently obtained anti-hypertensive drugs for treatment. Rosendoff (2015) stated that the risk of $\mathrm{CAD}$ in the patients with hypertension has shown to be greatly reduced with effective anti-hypertensive therapy. Therefore, treatment has the main effect to prevent the risk factor of CAD because it affected to lower blood pressure. Kjeldsen (2017) also mentioned the individuals with high blood pressure and no other risk factor have low risk in cardiovascular disease.

Jennings (2015) indicated that patients who had hypertension and knew they have coronary disease were likely to be more receptive to obtain treatment recommendations including those related to physical activity and nutrition. Some more extensive guidance on non-drug measures, such as early diagnosis and health promotion, for this population would be welcome. As contended by Kjeldsen (2017), anti-hypertensive treatment strategies such as initiation and intensity of treatment, use of drug combination, as well as other treatments applied for those patients in high risk. 
Besides, for lower risk individuals, they may obtain other different treatments from those in high risk individuals. This was because of the evidence found in high risk people blood pressure control was more difficult and required more frequently the combination of anti-hypertensive drugs together with other therapy first of all statin treatment (Kjeldsen, 2017).

Life style is an obvious reason about why the hypertension prevalence always high in Surabaya, particularly salt consumption. Indonesians frequently take a high consumption of salt for their food because they prefer to add salt in order to make delicious taste. As eloquently stated by the data of 2013 Basic Health Research (Riskesdas), $48.6 \%$ of males and $47.7 \%$ of females consumed the salt 1-6 times per week. Aprillia (2007) in her study revealed that there was correlation between consumption of salt and blood pressure in patients who attended at Dr. Soetomo Health Care Services Surabaya. Her respondents indicated a high intake of salt with 4-5 times or more than 5 gram because the recommended of salt consumption is less by 5 gram (Aprillia, 2007).

Hypertension relates to diet especially food contained salt and the food processing may be high in salt. In addition, people used to add salt for taste. Dietary salt increased blood pressure in most of the people with hypertension, and in about a quarter of those with normal blood pressure, particularly with growing age. An excessive intake of salt independently would increase the risk of CVD in overweight people (Mackay \& Mensah, 2004). So, lowering dietary salt is the recommendation for patients in the risk of hypertension. In other words, the treatment with anti-hypertensive drugs for high risk patients still implement as the strategy for initiation and intensity of treatment but it may be different from those patients in lower risk (Kjeldsen, 2017).

Investigation among other studies, they showed as same as the result that there was interaction between sex and CAD (Xu et al., 2017; Yang et al., 2015). Furthermore, many studies documented that there was a sex difference in the burden of risk factors among patients with CAD (Lotfi-Tokaldany et al., 2017). Overall, $49 \%$ of males and $32 \%$ of females over 40 years are at risk of CAD in their life (Jacobs, 2009).

Most of CAD patients here were males like other studies also showed that males were more likely to occurred CAD compared to females (Yulsam, et al., 2015; Susilo, 2015; Zahrawardani, et al., 2013). Nonetheless, the majority of the risk factors for CAD was similar for male and female (Yahagi et al., 2015) including high blood pressure as the modifiable risk. Another study also concluded higher rates of CAD among male compared with female (Mackay \& Mensah, 2004).

A study in Finland revealed that the incidence of CAD in men was approximately three times higher and mortality was approximately five times higher than in women (Jousilahti et al., 1999). The CAD prevalence was higher in males than in females because men's characteristics such as the incidence of angina, total cholesterol ratio, smoking habits and serum creatinine were higher in males than females (Jousilahti et al., 1999; $\mathrm{Xu}$ et al., 2017). Besides, the differences in serum total cholesterol level, body mass index, blood pressure, and diabetes indicates about $1 / 3$ of the age-related increase in CAD risk among men and 50\%-60\% among women (Jousilahti et al., 1999). Xu et al. (2017) added the fact that the male sex had an odds ratio of 1.96 which implied a male patient has 1.96 times higher risk of CAD than in females. The onset of CAD in males usually obtains from myocardial infarction or sudden coronary death (Papakonstantinou et al., 2013). Cholesterol profiles of males and females particularly levels of low-density lipoproteins were lower in women than in men until the age of 50 (Yahagi et al., 2015). Hormonal status has known 
influencing $\mathrm{CAD}$ risk in male because women has estrogen with its impact of protective from atherosclerosis events (Braundwald \& Antman, 2010). Those sex differences explained the most of the risk factors were more favorable in females but the sex difference diminished with increasing age (Yahagi et al., 2015).

According to Duenas et al. (2011), although males experience $\mathrm{CAD}$ four times more than females, females were more likely to die after the first episode of an acute myocardial infarction. In cardiac anatomy-biology, females have smaller and stiffer hearts than males (RegitzZagrosek et al., 2010), as left ventricular mass is higher in men than in women after puberty (Campbell et al., 2011). Furthermore, the females' vasculature is also smaller and stiffer (Duenas et al., 2011).

CAD in females lags behind males by $10-15$ years as the result of the protecting effect of estrogen on atherosclerosis and decreasing the risk factors in younger women (Burke et al., 2001). Moreover, women compared to men had a lower burden of CAD with up to $50 \%$ at age $30-44$ group and $40 \%$ at age 45-59 group (Chiha et al., 2015). Estrogens played a significant role in the difference of CAD (Papakonstantinou et al., 2013). There are many benefits from estrogen in biologic mechanism including: (1) increasing HDL and decreasing LDL cholesterol levels; (2) enhancing the release of nitric oxide from endothelial cells so that resulting in increasing vasorelaxation; (3) endothelium dependent vasodilation and (4) positive effect of hemostatic (Humphries et al., 2017). However, women have higher risk of hypertension than men because the factor of its disorder related to pregnancy and reproduction specifically preeclampsia, hypertensive disorder of pregnancy, menarche, menopause and gestational diabetes (Mehta et al., 2016). In addition, cholesterol profiles of women and men differ with age such as when low-density lipoproteins levels increased in women after the age of 50 so this change lipid levels may increase $\mathrm{CAD}$ in older women (Yahagi et al., 2015).

In women, the role of menopause has a crucial part as risk factors for CAD because the CAD risk will increase after the menopause (Yahagi et al., 2015). After menopause, low density lipoprotein cholesterol level and the total cholesterol level in women increased (Papakonstantinou et al., 2013). Early menopause before age 45 also showed to be related with an increased CAD risk as compared to women in whom menopause occurs later than 45 years old (Muka et al., 2016). Early menarche significantly associated with an increased risk of CAD mainly women who have early menarche at age 10 (Canoy et al., 2015). In addition, women who smoke and have high triglyceride levels, diabetes, obesity and depression are at higher risk of CAD than men who smoke (Mackay \& Mensah, 2004; Humphries et al., 2017). Depression in women refers to early life trauma and symptoms of PTSD (Post Traumatic Stress Disorders) which related to increased risk of CAD even in younger women (Korkeila et al, 2010; Edmondson et al, 2013).

Generally, compared to males, females were more vulnerable to high blood pressure, hypercholesterolemia, peripheral vascular disease, diabetes mellitus, and unstable angina (Papakonstantinou et al., 2013). Furthermore, despite females have less extensive disease among patients with unstable and stable angina pectoris compared to males, the former have more severe symptoms (Tamis-Holland et al., 2011). Moreover, even left ventricular systolic dysfunction was less frequent in females; they more often have congestive heart failure (Papakonstantinou et al., 2013). Female patients with CAD also receive less intensive treatment than male patients (Lawesson et al., 2012) because they neglect health care needs due to their household obligation (Duenas et al., 2011). 
The rate of coronary death in women with CAD was twice higher than in men after myocardial infarction and revascularization procedure (Papakonstantinou et al., 2013).

The difference of the burden CAD between women and men is confirmed by presenting with chest pain and the investigation of suspected angina (Chiha et al., 2015). Furthermore, CAD was accompanied by more severe symptoms of typical or atypical angina in women than in men for any given extent of disease (Papakonstantinou et al., 2013). Cardiovascular diseases including CAD still remain the most common cause of death in non-communicable disease for both women and men (Yahagi et al., 2015). According to the risk factor from some studies between men and women suggested categorizing the modifiable risk factors of CAD into specific groups of men and women. It can improve the prevention of $\mathrm{CAD}$ and reduce the sudden coronary death.

\section{CONCLUSION}

The study showed significant relationship between hypertension and CAD. Another finding showed statistically significant the interaction between sex and CAD among the cardiovascular polyclinic in Jemursari Islamic Hospital Surabaya. Hypertension and sex were significant as the risk factors of CAD.

This study suggest to reduce the intake of salt in dietary of daily life to prevent from hypertension, to obtain antihypertensive drugs for lowering the CAD risk and to divide the modifiable risk factors between men and women to prevent CAD because even all most of the risk factors were similar but there were some were unique case in women.

\section{REFERENCE}

Aprillia, B., 2007. Hubungan antara Status Gizi, Konsumsi Garam serta
Keteraturan Minum Obat dengan

Tekanan Darah Penderita

Hipertensi (Studi di Puskesmas dr.

Soetomo Kecamatan Tegalsari

Kota Surabaya). Undergraduate

Thesis. Surabaya: Universitas Airlangga FKM UNAIR.

Braundwald, E. \& Antman, E.M., 2010. Harrison's Principles of Internal Medicine. 17th ed. New Jersey: Mc Graw Hill.

Burke, A.P., Farb, A., Malcom, G. \& Virmani, R., 2001. Effect of Menopause on Palque Morphologic Characteristics in Coronary Atherosclerosis. American Heart Journal, (141).

Campbell, D.J. Somaratne, J.B., Jenkins, A.J., Prior, D.I., Yii, M., Kenny, J.F., Newcomb, A.E., Kelly, D.J., \& Black, M.J., 2011. Differences in Myocardial Structure and Coronary Microvasculature between Men and Women with Coronary Artery Disease. Hypertension, (57).

Canoy, D. Beral, V., Balkwill, A., Wright, F.L., Kroll, M.E., Reeves, G.K., Green, J., \& Cairns, B.J., 2015. Age at Menarche and Risk od Coronary Heart and Other Vascular Diseases in a Large UK Cohort. Million Women Study Cardiovascular, (131).

Chiha, J. Mitchell, P., Gopinath, B., Plant, A.J.H., Kavoor, P., \& Thiagalingam, A., 2015. Gender Differences in the Severity and Extent of Coronary Artery Disease. IJC Heart \& Vasculature, (8).

Duenas, M., Ramirez, C., Arana, R. \& Faide, I., 2011. Gender Differences and Determinants of Health Related Quality of Life in Coronary Patients: A Follow Up Study. BMC Cardiovascular Disorders, (11).

Dinas Kesehatan Jawa Timur, 2016. Profil Kesehatan Provinsi Jawa Timur 2015. Annual Report. Surabaya: Kementerian Kesehatan RI Kementerian Kesehatan RI. 
Dinas Kesehatan Kota Surabaya, 2017. 10 Penyakit Terbanyak Januri Desember 2016. [Online]

Edmondson, D. Kronish, L.M. Shaffer, J.A., Falzon, L., \& Burg, M.M., 2013. Posttraumatic Stress Disorder and Risk of Coronary Heart Disease: a Meta-analytic Review. American Heart Journal, (166).

Franklin, S.S., Larson, M.G. \& Khan, S.A., 2001. Does the Relation of Blood Pressure to Coronary Heart Disease Risk Change with Aging? The Framingham Heart Study. Circulation, (103).

Hanson, M.A. Fareed, M.T., Argenio, S.L., Agunwamba, A.O., \& Hanson T. R., 2013. Coronary Artery Disease. Rochester: El Sevier.

Hansson, G.K., 2005. Inflammation, Atherosclerosis and Coronary Artery Disease. The New England Journal of Medicine, XVI(352).

Humphries, K.H. Izadnegahdar, M., Sedlak, T., Saw, J., Johnston, N., Schenck-Gustafsson, K., Shah, R.U., Regitz-Zagrosek, V., Grewal, J., Vaccarino, V., Wei, J., \& Bairey Merz, C.N., 2017. Sex Differences in Cardiovascular Disease - Impact on Care and Outcomes. Frontiers in Neuroendocrinology, (46).

Jacobs, A.K., 2009. Coronary Intervention in 2009: Are Woman No Different than Men? Circulation Cardiovascular Intervention, (2).

James, P.A., Oparil, S. \& Carter, B.I., 2014. Evidence-Based Guideline for the Management of High Blood Pressure in Adults: Report from the Panel Members Appointed to the Eight Joint National Committee 8. Journal American Medical Association, (311).

Jennings, G.L.R., 2015. A New Guideline on Treatment of Hypertension in Those with Coronary Artery Disease: Scientific Statement from the American Heart Association, American College of Cardiology, and American Society of Hypertension about Treatment of Hypertension. Heart, Lung and Circulation, (24).

Joint National Committee VII, 2004. The Seventh Report of the Joint National Committee on Prevention, Detection, Evaluation and Treatment of High Blood Pressure. Complete Report. New York: NIH Publication US Department of Health and Human Services.

Jousilahti, P., Vartiainen, E., Tuomilehto, J. \& Puska, P., 1999. Sex, Age, Cardiovascular Risk Factors and Coronary Heart Disease: A Prospective Follow-Up Study of 14786 Middle-Aged men and Women in Finland. Circulation, (99).

Kementerian Kesehatan RI, 2013. Riset Kesehatan Dasar 2013. Health Report. Jakarta: Kemenkes RI Badan Litbangkes Kemenkes RI.

Kjeldsen, S.E., 2017. Hypertension and Cardiovascular Risk: General Aspects. Pharmacological Research, III(11).

Korkeila, J. Vahtera, J., Korkeila, K., Kivimaki, M., Sumanen, M., Kosvenvuo, K., \& Kosvenvuo, M., 2010. Childhood Adversities as Predictors of Incident Coronary Heart Disease and Cerebrovascular Disease. Heart, (96).

Kotseva, K., Jennings, C.S. \& Turner, E.L., 2012. ASPIRE-PREVENT: A Survey of Lifestyle, Risk Factor Management and Cardio protective Medication in Patients with Coronary Heart Disease and People at High-Risk of Developing Cardiovascular Disease in the UK. Heart, (98).

Lawesson, S., Alfredsson, J., Frederikson, M. \& Swahn, E., 2012. Time Trends in STEMI - Improved Treatment and Outcome but Still A Gender Gap: A Prospective Observational Cohort Stud from the 
SWEDEHEART Register. BMJ Open, (2).

Lee, R.M., 2000. Unobtrusive Methods in Social Research. Buckingham: Open University Press.

Lee, S.E., Lee, H.Y., Cho, H.J., Choe, W.S., \& Oh, B.H., 2017. Reverse JCurve Relationship between OnTreatment Blood Pressure and Mortality in Patients with Heart Failure. JACC: Heart Failure, $\mathrm{V}(11)$.

Lotfi-Tokaldany, M., Abbasi, S.H., Karimi, A., Kassaian, S.E., Davarpasand, T., Jalali, A., \& Sadeghian, S., 2017. SexDependent Effects of Diabetes Mellitus on the Revascularization Rate in Mid-Term Follow Up of Young Patients with Coronary Artery Disease. Journal of Diabetes and Its Complications, (31).

Mackay, J. \& Mensah, G.A., 2004. the Atlas of Heart Disease and Stroke. Geneva: WHO.

McEvoy, J.W. Post, W.S., Blumnethal, R.S., Blaha, M., Psaty, B.M., Budoff, M.J., Nasir, K., \& Faisal, R., 2017. Relation of Diastolic Blood Pressure and Coronary Artery Calcium to Coronary Events and Outcomes (from the Multiethnic Study of Atherosclerosis). The American Journal of Cardiology, VII(94).

Medical Record of RSI Jemursari. 2017. Medical Record of RSI Jemursari in Cardiovascular Polyclinic of Jemursari Islamic Hopital April 2017. [Medical Record]. SIMRS Jemursari Surabaya: Medical Record RSI Jemursari.

Mehta, L.S., Beckie, T.M., DeVon, H.A., Grines, C.L., Krumholz, H.M., Johnson, M.N., Lindley, K.J., Vaccarino, V., Wang, T.Y., Watson, K.E., \& Wenger, N.K., 2016. Acute Myocardial Infarction in Women: A Scientific Statement from the American Heart Association. Circulation, (133).

Muka, T. Oliver-William, C., Kunutsor, S., Laven, J.S. Fauser, B.C., Chowdhury, R., Kavousi, M., \& Franco, O.H., 2016. Association of Age at Onset of Menopause and Time since Onset of Menopause with Cardiovascular Outcomes, Intermediate Vascular Traits, and All-Cause Mortality: A Systematic Review and Meta-Analysis. JAMA Cardiovascular, (1).

Naga, 2012. Buku Panduan Lengkap Penyakit Dalam. Jakarta: Diva Press.

Papakonstantinou, N.A. Stamou, M.I., Baikoussis, N.G., Goudevenos, J., \& Apostolakis, E., 2013. Sex Differentiation with regard to Coronary Artery Disease. Journal of Cardiology, (62).

Pusat Data dan Informasi Kesehatan RI, 2014. Info Datin: Situasi Kesehatan Jantung. Annual Health Report. Jakarta: Pusdatin Kemenkes RI Kementerian Kesehatan RI.

Regitz-Zagrosek, V., Oertlet-Prigione, S., Seeland, U. \& Hetzer, R., 2010. Sex and Gender Differences in Myocardial Hypertrophy and Heart Failure. Circulation Journal, (74).

Rosendoff, C. Lackland, D.T., Allison, M.T., Black, H.R., Blumenthal, R.S., Findeiss, L., Gersh, B.J., Gore, J.M., Levy, D., Long, J.B., O'Connor, C.M., Ogedegbe, O., O'Gara, P.T., Cannon, C., de Lemos, J.A., Elliot, W.J., Oparil, S., \& White, W.B., 2015. Treatment of Hypertension in Patients with Coronary Artery Disease. Journal of the American College of Cardiology, 65(18).

Susilo, C., 2015. Identifikasi Faktor Usia, Jenis Kelamin dengan Luas Infark Miokard pada Penyakit Jantung Koroner di Ruang ICCU RSD dr. 
Soebandi Jember. The Indonesia's Journal of Health Science, VI(1).

Tamis-Holland, J.E. Lu, J., Bittner, V., Magee, M.F., Lopes, N., Adler, D.S., Kip, K.E., Schwartz, I., Groenewoud, Y.A., \& Jacobs, A.K., 2011. BARI 2D Study Group, Sex, Clinical Symptoms, and Angiographic Findings in Patients with Diabetes Mellitus and Coronary Artery Disease (from the Bypass Angioplasty Revascularization Investigation 2 Diabetes Trial). American Journal of Cardiology, (107).

Vishram, J.K., Borglykke, A., Andreasen, A.H., Jeppesen, J., Ibsen, H, Jorgensen, T., Broda, G., Palmieri, L., Glampaoli, S., Donfransesco, C., Kee, F., Mancia, G., Cesana, G., Kuulasma, K., Sans, S., \& Olsen, M.H., 2012. On Behalf of the MORGAM Project Impact of Age on the Importance of Systolic and Diastolic Blood Pressure for Stroke Risk:the MOnica, risk, genetics, archiving and monograph. Hypertension, LX.

WHO, 2016. Classification of Diseases. [Online].

Xu, H. Duan, Z., Miao, C., Gengm S., \& Jin, Y., 2017. Development of A Diagnosis Model for Coronary Artery Disease. Indian Heart Journal, (69).
Yahagi, K., Davis, H.R., Arbustini, E. \& Virmani, R., 2015. Sex Differences in Coronary Artery Disease: Pathological Observations. Journal of Atherosclerosis, I(17).

Yulsam, P.Y., Oenzil, F. \& Efrida, 2015. Insidens Riwayat Hipertensi dan Diabetes Melitus pada Pasien Penyakit Jantung Koroner di RS Dr. M. Djamil Padang. Jurnal Kesehatan Andalas, 4(2).

Yang, Y. Chen, L., Yam, Y., Achenbach, S., Al-Mallah, M., Berman, D.S., Budoff, M.J., Cademartiri, F., Callister, T.Q., Chang H., Chengm V.Y., Chinnaiyan, K., Cury, R., Delago, A., Dunning, A., Feuchtner, G., Hadamitzky, M., Hausleiter, J., Karlsberg, R.P., Kaufmann, P.A., Kim, Y., Leipsic, J., LaBounty, T., Lin, F., Maffei, E., Raff, G.L., Shaw, L.J., Villines, T.C., Min, J.K., \& Chow, B.J.W., 2015. A Clinical Model to Identify Patients with High-Risk Coronary Artery Disease. JACC: Cardiovascular Imaging, VIII(4).

Zahrawardani, D., Herlambang, K.S. \& Anggraheny, H.D., 2013. Analisis Faktor Risiko Kejadian Penyakit Jantung Koroner di RSUP Dr Kariadi Semarang. Jurnal Kedokteran Muhammadiyah, I(2). 